\title{
Mapping Particle Size and Soil Organic Matter in Tropical Soil Based on Hyperspectral Imaging and Non-Imaging Sensors
}

\author{
Marcos Rafael Nanni ${ }^{1}{ }^{(0)}$, José Alexandre Melo Demattê ${ }^{2}{ }^{\circledR}$, Marlon Rodrigues ${ }^{1}{ }^{(D}$, \\ Glaucio Leboso Alemparte Abrantes dos Santos ${ }^{1}{ }^{\mathbb{D}}$, Amanda Silveira Reis ${ }^{1} \mathbb{D}^{\mathbb{D}}$, Karym Mayara de Oliveira $^{1}$, \\ Everson Cezar ${ }^{1}$ (D), Renato Herrig Furlanetto ${ }^{1}$, Luís Guilherme Teixeira Crusiol ${ }^{1,3}$ and Liang Sun ${ }^{3, *}$ (D) \\ 1 Department of Agronomy, State University of Maringá, Maringá 87020-900, PR, Brazil; \\ mrnanni@uem.br (M.R.N.); pg53382@uem.br (M.R.); pg53377@uem.br (G.L.A.A.d.S.); \\ pg53376@uem.br (A.S.R.); pg54640@uem.br (K.M.d.O.); ecezar2@uem.br (E.C.); pg53830@uem.br (R.H.F.); \\ pg53403@uem.br (L.G.T.C.) \\ 2 Department of Soil Science, University of São Paulo, Piracicaba 13418-900, SP, Brazil; jamdemat@usp.br \\ 3 Key Laboratory of Agricultural Remote Sensing, Ministry of Agriculture/CAAS-CIAT Joint Laboratory in \\ Advanced Technologies for Sustainable Agriculture-Institute of Agricultural Resources and Regional \\ Planning, Chinese Academy of Agricultural Sciences, Beijing 100081, China \\ * Correspondence: sunliang@caas.cn
}

Citation: Nanni, M.R.; Demattê, J.A.M.; Rodrigues, M.; Santos, G.L.A.A.d.; Reis, A.S.; Oliveira, K.M.d.; Cezar, E.; Furlanetto, R.H.; Crusiol, L.G.T.; Sun, L. Mapping Particle Size and Soil Organic Matter in Tropical Soil Based on Hyperspectral Imaging and Non-Imaging Sensors. Remote Sens. 2021, 13, 1782. https://doi.org/ $10.3390 /$ rs13091782

Academic Editor: Travis W. Nauman

Received: 10 March 2021

Accepted: 26 April 2021

Published: 3 May 2021

Publisher's Note: MDPI stays neutral with regard to jurisdictional claims in published maps and institutional affiliations.

Copyright: (c) 2021 by the authors. Licensee MDPI, Basel, Switzerland. This article is an open access article distributed under the terms and conditions of the Creative Commons Attribution (CC BY) license (https:// creativecommons.org/licenses/by/ $4.0 /)$.
Abstract: We evaluated the use of airborne hyperspectral imaging and non-imaging sensors in the Vis-NIR-SWIR spectral region to assess particle size and soil organic matter in the surface layer of tropical soils (Oxisols, Ultisols, Entisols). The study area is near Piracicaba municipality, São Paulo state, Brazil, in a sugarcane cultivation area of 135 hectares. The study area, with bare soil, was imaged in April 2016 by the AisaFENIX aerotransported hyperspectral sensor, with spectral resolution of $3.5 \mathrm{~nm}$ between 380 and $970 \mathrm{~nm}$, and $12 \mathrm{~nm}$ between 970 and $2500 \mathrm{~nm}$. We collected 66 surface soil samples. The samples were analyzed for particle size and soil organic matter content. Laboratory spectral measurements were performed using a non-imaging spectroradiometer (ASD FieldSpec 3 Jr). Partial Least Square Regression (PLSR) was used to predict clay, silt, sand and soil organic matter (SOM). The PLSR functions developed were applied to the hyperspectral image of the study area, allowing development of a prediction map of clay, sand, and SOM. The developed PLSR models demonstrated the relationship between the predictor variables at the cross-validation step, both for the non-imaging and imaging sensors, when the highest $\mathrm{r}$ and $\mathrm{R}^{2}$ values were obtained for clay, sand, and SOM, with $\mathrm{R}^{2}$ over 0.67 . We did not obtain a satisfactory model for silt content. For the non-imaging sensor at the prediction step, $\mathrm{R}^{2}$ values for clay and SOM were over 0.7 and sand was lower than 0.54 . The imaging sensor yielded models for clay, sand, and SOM with $\mathrm{R}^{2}$ values of $0.62,0.66$, and 0.67 , respectively. Pearson correlation between sensors was greater than 0.849 for the prediction of clay, sand, and SOM. Our study successfully generated, from the imaging sensor, a large-scale and detailed predicted soil maps for particle size and SOM, which are important in the management of tropical soils.

Keywords: PLSR; proximal sensing; remote sensing; soil attributes

\section{Introduction}

Brazil has a great soil diversity due to a range of topography, biota, climate, and parent materials among the soil-forming factors. Agriculture is the main economic activity in Brazil and, therefore, the knowledge of pedogenetic processes and the capacity to differentiate soil classes are essential to improve soil management and productivity [1].

However, detailed, or even semi-detailed, soil use maps are rare in Brazil and, according to Mendonça-Santos [2] and Santos et al. [3], only $0.25-1 \%$ of available soil maps are plotted on an adequate scale. Furthermore, soil map production requires numerous on-theground observations and sample collection. The use of mathematical models obtained via 
hyperspectral sensors is an alternative technique to traditional soil maps that can derive quantified soil information. Digital soil mapping (DSM) produces adequate information quickly and economically but must be linked to measured soil attributes.

Clay content and soil organic matter (SOM) are two attributes that reflect and influence soil fertility. This is due to their strong relationship with other soil properties and functions such as ion exchange dynamics, preservation of organic C [4], water retention, structure and chemistry [5]. Agricultural areas require soil quality assessment for their best use and management. Most soils available for cultivation in Brazil are in the Oxisol or Ultisol soil Order. These soils have limited natural fertility due to pedogenesis under a hot and humid climate. Soil mineralogy, granulometry, and soil organic matter content affect soil management decision and are key properties for digital modeling [6].

Soil properties including clay and SOM are conventionally determined by laboratory analysis. The results are reliable, but are expensive, sample destructive, time- consuming, and require reagents that may be harmful to the environment [7]. Clay content is a primary attribute that has a physical relationship with electromagnetic radiation [6]. For this reason, remote sensing techniques, e.g., diffuse reflectance spectroscopy (DRS), have been evaluated for rapid estimation of soil texture in a non-destructive and low cost, providing rapid response compared to conventional laboratory analyses [7-11].

Numerous studies have been carried out using Vis-NIR-SWIR reflectance spectroscopy to differentiate soil types [12] and to predict soil attributes, such as granulometry [13] and organic matter [14-16]. Vasques et al. [17] combined spectral data at different depth intervals and predicted soil classification in the Brazilian Soil Classification System.

Initially, this technique was limited to laboratory studies because of sensors characteristics. However, the use of field and airborne sensors has increased considerably [18], and has been used to detect soil color, clay content, and mineral composition [11]; estimate soil organic C content [19]; and selected soil biochemical, physical, and mineralogical properties [20] with in situ measurements. Soil data collected by airborne hyperspectral sensors has shown to be a promising technique for understanding soil attributes and spatial patterns $[18,21,22]$. The use of this technique for prediction of the soil characteristics and properties has demonstrated challenges such as large datasets, spectral instability effects, and atmospheric interference [23-26].

Thus, the appropriate interpretation of spectral data both in the laboratory and field using different sensors is not clearly understood. This diminishes the practical value of Vis-NIR - SWIR spectroscopy even as its use has expanded, requiring, thus, further scientific investigations. Our hypothesis is that predicting particle size and soil organic matter through hyperspectral imaging and non-imaging sensors will yield comparable results to traditional analytical techniques. This study evaluates use of hyperspectral imaging and non-imaging sensors for predicting particle size and soil organic matter in a selected soil landscape.

\section{Materials and Methods}

\subsection{The Study Area}

The study area (Figure 1) is located between the municipalities of Piracicaba and Santa Bárbara d'Oeste, in the Tupi district, state of São Paulo (SP), Brazil, $\left(22^{\circ} 42^{\prime} 39.16^{\prime \prime}\right.$, $\left.47^{\circ} 30^{\prime} 59.3^{\prime \prime} \mathrm{W}\right)$. The area is in a sugarcane cultivation of 135 hectares near the Piracicaba River (Figure 1). The climate is Cwa-humid subtropical (Köppen), with an average annual temperature of $21.6^{\circ} \mathrm{C}$ and annual rainfall of $1278 \mathrm{~mm}$ (ESALQ/USP weather station). 


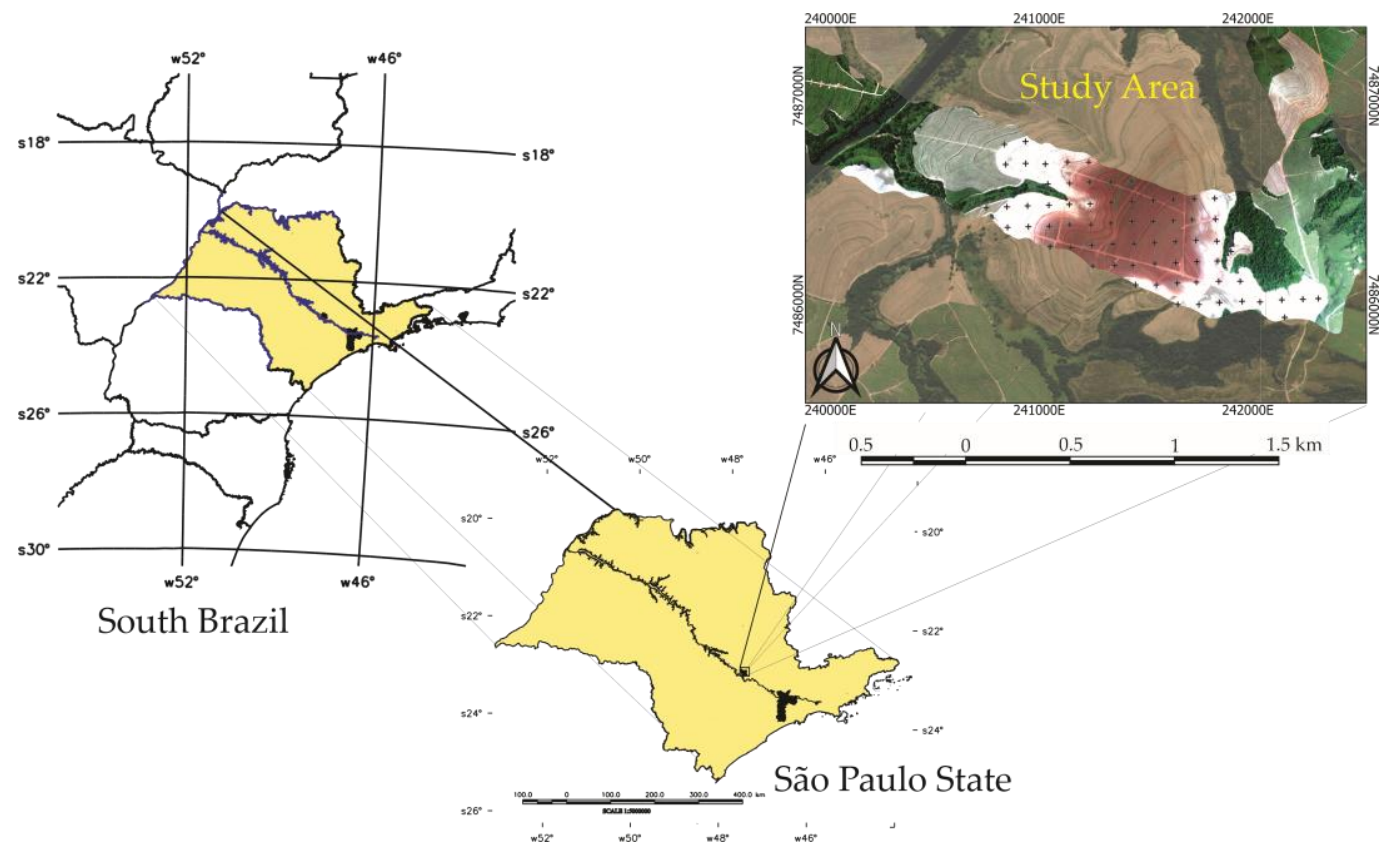

Figure 1. Location of the study site and sampling points (+).

The soil landscape is characterized by rolling hills with rounded summits and smooth slopes with lengths varying from 200 to $1500 \mathrm{~m}$. Narrow valleys are cut into and separate the hillslopes. Elevation ranges between 532 to $570 \mathrm{~m}$. Three soil orders Oxisols, Entisols, and Ultisols occur in the area.

Oxisols predominate on gentle, planar slopes and summits in the higher portions of the landscape. Ultisols occur on steeper slopes and Entisols occupy floodplains or low stream terraces (Figure 2). Soil texture varies from sandy to clayey. Both the clayey and sandy soils are derived from parent materials from members of the Permian age Irati, Tatuí, and Itararé formations [27-33].

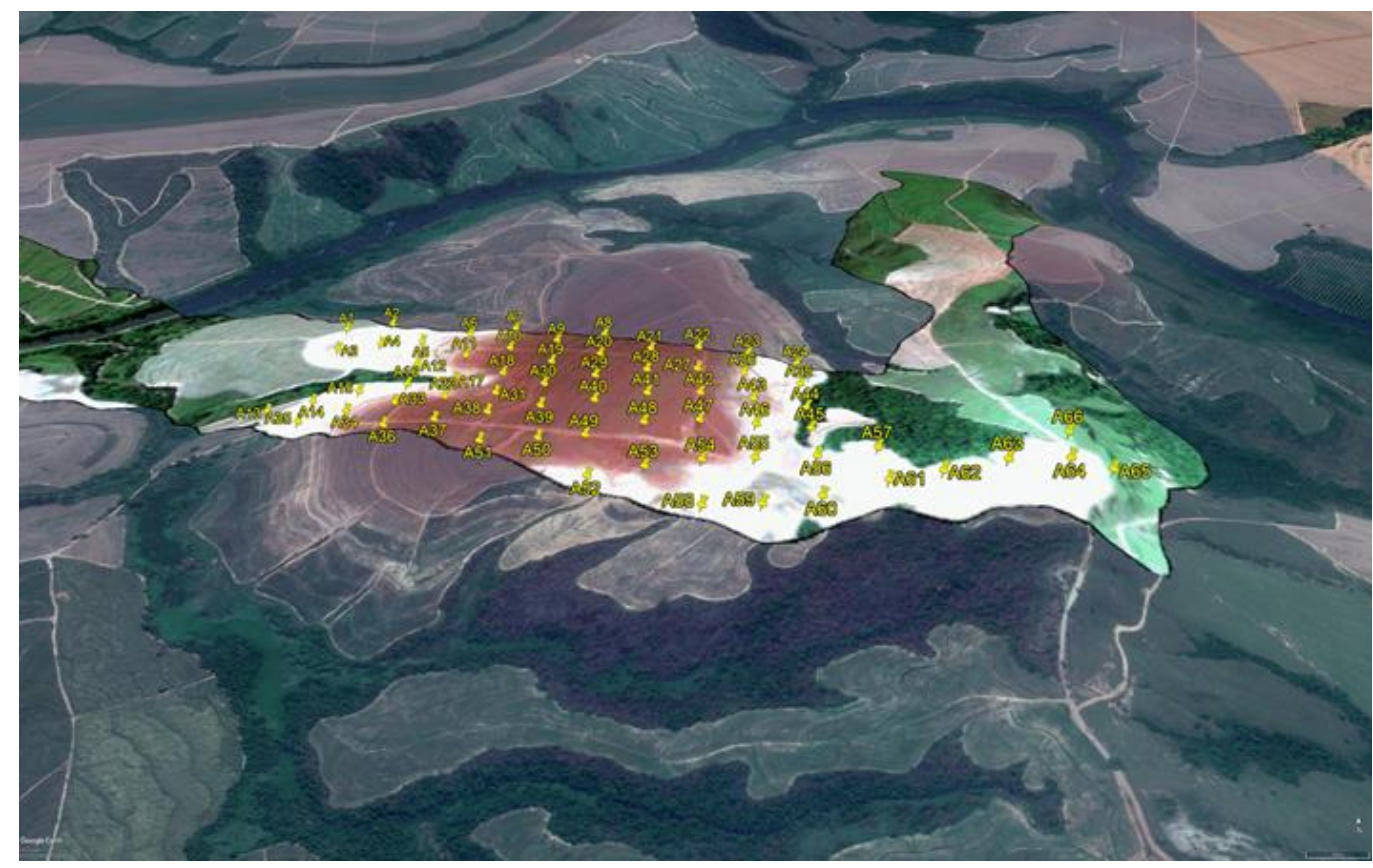

Figure 2. Topography of the study area and location of the collected samples. 
A total of 66 soil samples (0-20 cm depth-Figure 2) was uniformly distributed over the area and collected in July 2017. The soil samples were analyzed for particle size by the pipette method and wet sieving using $0.1 \mathrm{~mol} \mathrm{~L}^{-1} \mathrm{NaOH}$ as a dispersing agent. Soil organic matter was obtained by determining the organic carbon content (Walkley-Black method) and subsequent multiplication by the 1.724 factor according to Teixeira et al. [34]. The descriptive analysis was carried out with the STATISTICA v. 12 software (StatSoft, Tulsa, OK, USA).

\subsection{Non-Imaging Sensor Data Acquisition and Processing}

For the spectral analysis in the laboratory, the samples were previously dried at $45^{\circ} \mathrm{C}$ for $48 \mathrm{~h}$, sieved in mesh with $2 \mathrm{~mm}$ to homogenize particles and to reduce humidity and sampling effects [35]. Afterward each sample was put on a Petri dish (with a diameter of $9 \mathrm{~cm}$ and $1.5 \mathrm{~cm}$ in height) and samples were subjected to spectral measurements. Reflectance curves were obtained by a ASD Fieldspec 3 Jr spectroradiometer (ASD, Boulder, CO, USA), with a spectral resolution of $3 \mathrm{~nm}$ between 350 and $1400 \mathrm{~nm}$ and $30 \mathrm{~nm}$ between 1400 and $2500 \mathrm{~nm}$. Before obtaining spectral readings, the calibration in the non-imaging sensor (standard equipment) was performed using the Spectralon standard white plate as the maximum reflectance reference, according to Labsphere Reflectance Calibration Laboratory [36]. The optical fiber was attached to the pistol grip and placed on a support platform in a vertical position, at a distance of $8 \mathrm{~cm}$ from the samples. A $650 \mathrm{~W}$ halogen lamp with a non-collimated beam, located $35 \mathrm{~cm}$ from the platform and an angle of $30^{\circ}$ to the horizontal plane, was used as light source. The spectroradiometer was programmed to take 30 readings for each sample, thus leading to an average spectral curve, according to the Cezar et al. [13].

The spectral readings were carried out with three replicates for each sample while the Petri dish was successively replaced at $120^{\circ}$ clockwise, therefore analyzing the entire sample. Afterward a simple arithmetic mean of the three measurements was calculated, as described by Nanni and Demattê [37].

\subsection{Imaging Sensor Data Acquisition and Processing}

To compare the results of the data obtained by the spectroradiometer, considered standard equipment for obtaining spectral information when working with remote sensing $[13,38,39]$, hyperspectral aerial images were obtained by the AisaFENIX hyperspectral image sensor, with the Vis-NIR-SWIR spectral range, and spectral resolution of $3.5 \mathrm{~nm}$ between 380 and $970 \mathrm{~nm}$ and $12 \mathrm{~nm}$ between 970 and $2500 \mathrm{~nm}$.

A PA-34-200T Seneca II model twin-engined plane flew over the study area, on 30 April 2016, with the AisaFENIX imaging sensor and the GPS/IMU unit (OXTS-RT3050 model) installed on it, to collect the hyperspectral images and data related to the geometric correction of the image. The flight was performed at 14:35 p.m. (GMT) under open-sky conditions, fully sunny at an altitude of $660 \mathrm{~m}$, resulting in a spatial resolution of about $1 \mathrm{~m}$. Even though it is a sugar-growing region, the study area had bare soil, previously plowed and prepared for planting a new crop cycle.

The collected images by the sensor during the aerial assessment were pre-processed for geometric and radiometric correction through the CaliGeo PRO ${ }^{\circledR}$ software [40]. The input data files were the raw data (.raw) generated by the AisaFENIX sensor, the sensor calibration file (.cal and the LUT), and the dark reference file (.hdr) to optimize spectral radiation data quality. This resulted in radiance and radiometrically corrected images.

After atmospheric correction, the images were transformed from radiance to reflectance, standardizing the differences of lighting and sensors. To perform image processing (atmospheric/topographic correction), the ATCOR-4 software, based in MODTRAM algorithm [41] was used. This computational packet receives the input data, which is the images in the radiance unit and converts it into a reflectance unit.

Then, from the AisaFENIX hyperspectral image, spectral curves were collected at the correspondent location of each soil sample through the Z-profile tool, software ENVI 
5.1 [42]. The file was exported in txt format, then opened by the Excel software and the spectral curves were plotted, as well as the reflectance values of the points. Subsequently, the data was imported into The Unscrambler ${ }^{\circledR}$ software (CAMO Software, Oslo, Norway) for statistical analysis.

Wavelengths between 1350 and $1400 \mathrm{~nm}$ and between 1800 and $2000 \mathrm{~nm}$ were excluded due to the interference in their reflectance values (greater absorption) caused by atmospheric water vapor [43]. In addition, the Savitzky-Golay filtering and smoothing algorithm (2nd order polynomial) [44] was applied to the data using the ENVI 5.1 software.

\subsection{Multivariate Statistical Analysis and Mapping}

The statistical analyses were carried out by both sensors. Initially, the marginal wavelengths (350-399 and 2361-2500 nm for the FieldSpec) and (380-467 and 2128-2500 nm for the AisaFENIX), have been removed due to noise [18,19].

For the non-imaging sensor, each spectral curve was submitted to baseline and light scattering correction by first and second derivatives (Savitzky-Golay), standard normal variate (SNV) and multiplicative scatter correction (MSC). Based on the best results, it was chosen the multiplicative scatter correction (MSC) method, according to Buddenbaum and Steffens [45]. This process was necessary to mathematically reduce the noise and to prevent the negative influence on the quality of the adjusted models [46].

The Unscrambler ${ }^{\circledR}$ software (CAMO Software) was used to analyze major components to group samples and to identify possible atypical data for curves called outliers. Four samples that presented results not representative soils types of the area of interest and spectrally vastly different were excluded from the dataset to achieve better results not only in the calibration of the models but also in their validation.

Then prediction models of clay, silt, sand and organic matter contents were adjusted through partial least squares regression (PLSR) of data from AisaFENIX hyperspectral imaging sensor and from FieldSpec. To develop the statistical models, the 66 samples were randomly divided in two sets, independent of the soil orders. One set, composed of 46 samples (the calibration set), was used to calibrate the models and cross-validation testing, while the other set, composed of 20 samples (prediction set), was used to validate the calibrated models, according to Nanni et al. [47].

In the calibration step, matrices $X$ and $Y$ are modeled simultaneously to find the latent variables (PLS factors) in the wavelengths $(X)$ that best predict the measured parameter $(Y)$, thus, the data set is reduced to some factors, which are used in data prediction and construction of the statistical model [48]. The factor is characterized by the main changes observed in $X$, and, when this factor cannot explain any variation in the sample set, a second factor perpendicular to the first one will be used, and so on [49].

After data calibration, a cross-validation process was carried out, in which each sample used to build the model is tested. A leave-one-out cross-validation procedure was adopted to verify the prediction capability of the PLSR model for the calibration set. After the cross-validation step, the model was tested by assessing the ability to predict new samples from data that did not participate in the construction of the PLSR model.

The $\mathrm{R}^{2}$ was used for prior assessment of calibration (c) models. RMSEc (calibration root mean square error) was the subsequent parameter for analyzing the model adjustment. However, the best estimate of the calibration model future performance is the RMSEcV (which is obtained during the cross-validation phase), producing more realistic and independent results for the data used in the construction of models [50]. Systematic error (BIAS) was also used as an evaluation parameter. Finally, the PLSR regression coefficients were used to study the significant wavelengths used in PLSR.

In order to obtain qualitative visual information, maps of the clay, sand and SOM content estimated by PLSR were also drawn up over the study area. For this purpose, the mathematical model generated by PLSR in the calibration step from the hyperspectral image, was inserted in the raster calculator of the QGIS software (QGIS Development Team), 
which from the original image, calculated the estimate of each attribute over the entire area of the study. This process was carried out individually for each attribute mentioned.

\section{Results and Discussions}

\subsection{Descriptive Analysis of Soil Attributes}

Table 1 presents the results of the granulometric analysis and the SOM content of the 66 samples collected in the study area. The results confirm the contrasting aspect of the parent materials (siltstone and sandstone) observed in Figure 2. The measured data of particle-size of the samples were plotted in a USDA textural triangle (Figure 3).

Table 1. Soil samples evaluated in the study area and their respective levels of sand, silt, clay and SOM.

\begin{tabular}{|c|c|c|c|c|c|c|c|c|c|}
\hline \multirow{2}{*}{ Samples } & Sand & Silt & Clay & \multirow{2}{*}{$\begin{array}{l}\mathrm{SOM}^{1} \\
\mathrm{~g} \mathrm{dm}^{-3}\end{array}$} & \multirow{2}{*}{ Samples } & Sand & Silt & Clay & \multirow{2}{*}{$\begin{array}{l}\mathrm{SOM}^{1} \\
\mathrm{~g} \mathrm{~kg}^{-3}\end{array}$} \\
\hline & & $\mathrm{g} \mathrm{kg}^{-1}$ & & & & & $\mathrm{~g} \mathrm{~kg}^{-1}$ & & \\
\hline A1 & 830.00 & 40.00 & 130.00 & 4.52 & A34 & 780.00 & 30.00 & 190.00 & 7.11 \\
\hline A2 & 740.00 & 30.00 & 230.00 & 5.20 & A35 & 730.00 & 40.00 & 230.00 & 4.06 \\
\hline $\mathrm{A} 3$ & 770.00 & 40.00 & 190.00 & 6.20 & A36 & 590.00 & 80.00 & 330.00 & 15.26 \\
\hline A4 & 810.00 & 40.00 & 150.00 & 5.91 & A37 & 470.00 & 40.00 & 490.00 & 10.07 \\
\hline A5 & 800.00 & 20.00 & 180.00 & 8.50 & A38 & 410.00 & 30.00 & 560.00 & 9.50 \\
\hline A6 & 720.00 & 40.00 & 220.00 & 12.00 & A39 & 450.00 & 100.00 & 450.00 & 13.13 \\
\hline A7 & 650.00 & 40.00 & 310.00 & 7.02 & A40 & 430.00 & 40.00 & 530.00 & 14.15 \\
\hline A8 & 460.00 & 60.00 & 480.00 & 14.80 & A41 & 410.00 & 40.00 & 550.00 & 12.85 \\
\hline A9 & 490.00 & 100.00 & 410.00 & 12.76 & A42 & 390.00 & 80.00 & 530.00 & 9.52 \\
\hline A10 & 540.00 & 40.00 & 420.00 & 9.06 & A43 & 550.00 & 40.00 & 410.00 & 6.28 \\
\hline A11 & 630.00 & 20.00 & 350.00 & 4.15 & A44 & 570.00 & 40.00 & 390.00 & 5.07 \\
\hline A12 & 790.00 & 40.00 & 170.00 & 5.35 & A45 & 500.00 & 20.00 & 480.00 & 4.06 \\
\hline A13 & 730.00 & 100.00 & 170.00 & 6.74 & A46 & 360.00 & 30.00 & 610.00 & 8.50 \\
\hline A14 & 860.00 & 30.00 & 110.00 & 2.94 & A47 & 400.00 & 60.00 & 550.00 & 10.81 \\
\hline A15 & 740.00 & 70.00 & 190.00 & 8.13 & $\mathrm{~A} 48$ & 380.00 & 40.00 & 580.00 & 11.09 \\
\hline A16 & 800.00 & 30.00 & 170.00 & 5.07 & A49 & 490.00 & 50.00 & 460.00 & 12.20 \\
\hline A17 & 650.00 & 30.00 & 320.00 & 6.46 & A50 & 510.00 & 80.00 & 410.00 & 11.00 \\
\hline A18 & 730.00 & 40.00 & 230.00 & 6.46 & A51 & 460.00 & 30.00 & 510.00 & 14.80 \\
\hline A19 & 460.00 & 50.00 & 490.00 & 13.41 & A52 & 750.00 & 20.00 & 230.00 & 2.57 \\
\hline A20 & 420.00 & 40.00 & 540.00 & 12.48 & A53 & 430.00 & 60.00 & 510.00 & 6.00 \\
\hline A21 & 470.00 & 40.00 & 490.00 & 12.39 & A54 & 430.00 & 180.00 & 390.00 & 11.37 \\
\hline A22 & 530.00 & 20.00 & 450.00 & 9.40 & A55 & 530.00 & 80.00 & 390.00 & 8.22 \\
\hline A23 & 490.00 & 40.00 & 470.00 & 8.31 & A56 & 550.00 & 40.00 & 410.00 & 3.50 \\
\hline A24 & 700.00 & 20.00 & 280.00 & 4.50 & A57 & 800.00 & 20.00 & 180.00 & 9.52 \\
\hline A25 & 630.00 & 40.00 & 330.00 & 4.89 & A58 & 770.00 & 30.00 & 200.00 & 3.22 \\
\hline A26 & 500.00 & 20.00 & 480.00 & 9.80 & A59 & 730.00 & 50.00 & 220.00 & 7.02 \\
\hline A27 & 450.00 & 80.00 & 470.00 & 13.96 & A60 & 620.00 & 50.00 & 330.00 & 7.76 \\
\hline A28 & 470.00 & 40.00 & 490.00 & 13.13 & A61 & 640.00 & 90.00 & 270.00 & 4.06 \\
\hline A29 & 450.00 & 80.00 & 470.00 & 12.11 & A62 & 730.00 & 50.00 & 220.00 & 6.28 \\
\hline A30 & 450.00 & 60.00 & 490.00 & 15.07 & A63 & 610.00 & 120.00 & 270.00 & 6.37 \\
\hline A31 & 550.00 & 40.00 & 410.00 & 10.17 & A64 & 630.00 & 120.00 & 250.00 & 5.63 \\
\hline A32 & 590.00 & 60.00 & 350.00 & 10.07 & A65 & 760.00 & 40.00 & 200.00 & 4.61 \\
\hline A33 & 680.00 & 30.00 & 290.00 & 9.24 & A66 & 490.00 & 40.00 & 470.00 & 7.39 \\
\hline
\end{tabular}

${ }^{1}$ Soil organic matter. 


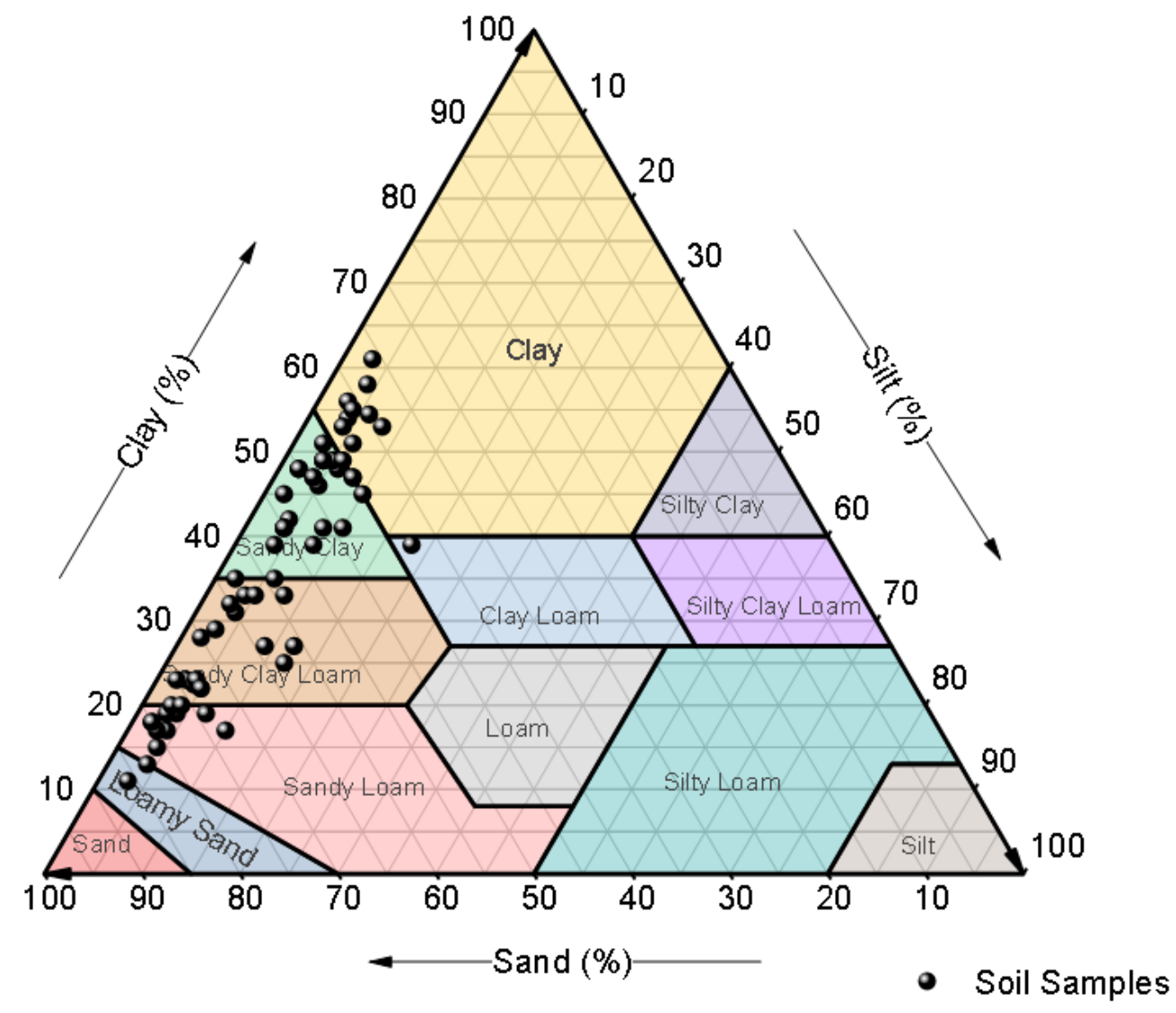

Figure 3. Particle-size of the samples plotted in a USDA textural triangle.

Table 2 presents the results from descriptive statistics of clay, silt, sand, and soil organic matter attributes. The coefficients of variation $(\mathrm{CV})$ showed high values for all evaluated attributes. According to Harr [51], the CV below 10\% are considered "low", between 15\% and 30\% "moderate", and greater than 30\% "high". Thus, the CVs were high for SOM, clay and silt and moderate to sand. The high variability for particle size fraction is explained by the influence of different parent materials on soils of the region, such as sandstone and siltstone [52], which presents varied mineralogical formation, consisting mainly of $\mathrm{Fe} / \mathrm{Al}$ oxides and Kaolinite, as reported by Vidal-Torrado and Lepsch [33].

Table 2. Descriptive statistic of particle size fraction and content of soil organic matter (SOM) from study area.

\begin{tabular}{ccccccc}
\hline Attributes & Minimum & Mean & Median & Maximum & SD $^{\mathbf{1}}$ & CV $^{\mathbf{2}}$ (\%) \\
\hline Sand $\left(\mathrm{g} \mathrm{kg}^{-1}\right)$ & 360.00 & 589.85 & 560.00 & 860.00 & 14.12 & 23.94 \\
Silt $\left(\mathrm{g} \mathrm{kg}^{-1}\right)$ & 20.00 & 50.45 & 40.00 & 180.00 & 2.93 & 58.01 \\
Clay $\left(\mathrm{g} \mathrm{kg}^{-1}\right)$ & 110.00 & 359.55 & 390.00 & 610.00 & 13.72 & 58.01 \\
SOM $\left(\mathrm{g} \mathrm{dm}^{-3}\right)$ & 2.57 & 8.53 & 8.26 & 15.26 & 0.35 & 41.28 \\
\hline
\end{tabular}

${ }^{1} \mathrm{SD}=$ Standard deviation; ${ }^{2} \mathrm{CV}=$ coefficients of variation.

For SOM, the high CV value is due to the high variation of the particle size fraction in the study area, since SOM is directly linked to the clay content for tropical soils [53], as observed in Table 3. Moreover, the agricultural use and management in the study area is also a determining factor [13], as there were places with and without the practice of removing crop residues from sugarcane cultivation. 
Table 3. Matrix of Pearson correlation coefficients between the soil attributes.

\begin{tabular}{ccccc}
\hline Attributes & Sand & Silt & Clay & SOM \\
\hline Sand & $1.00^{*}$ & -0.26 & $-0.98^{*}$ & $-0.65^{*}$ \\
Silt & -0.26 & $1.00^{*}$ & 0.04 & $0.27^{*}$ \\
Clay & $-0.98^{*}$ & 0.04 & $1.00^{*}$ & $0.62^{*}$ \\
SOM & $-0.65^{*}$ & $0.27^{*}$ & $0.62^{*}$ & $1.00^{*}$ \\
\hline
\end{tabular}

*. Correlation is significant at the 0.05 level.

\subsection{Spectral Description of Soils}

Figure $4 \mathrm{a}, \mathrm{b}$ demonstrate great variability in the reflectance of the evaluated soils, due to the difference in reflectance between soils developed from sandstone and siltstone formations, which can be seen in Figure $4 \mathrm{c}$,d. In fact, this result was expected because sandy soils tend to have much higher reflectance due to their mineralogical formation (rich in quartz) and due to their low levels of SOM [54] and opaque minerals [55]. In the case of the curves obtained by the airborne imaging sensor (Figure $4 \mathrm{~b}$ ), a higher concentration is observed among the curves, with a lower amplitude of the reflectance factor. This fact is probably due to the natural moisture of the soil (not collected at the time of imaging) which ends up reducing the albedo of sandy and silty soils, making them closer to the clayey portions of the area. When the samples are dried in the laboratory and the standardized humidity is maintained, as in the case of the non-imager sensor (Figure 4a), there is a gap between the curves of the sandy spots (higher reflectance across spectral range) and the clayey ones (lower reflectance). In addition, for this sensor, concavities can be observed at 450 and $2200 \mathrm{~nm}$ due to iron oxides and kaolinite, respectively [55].
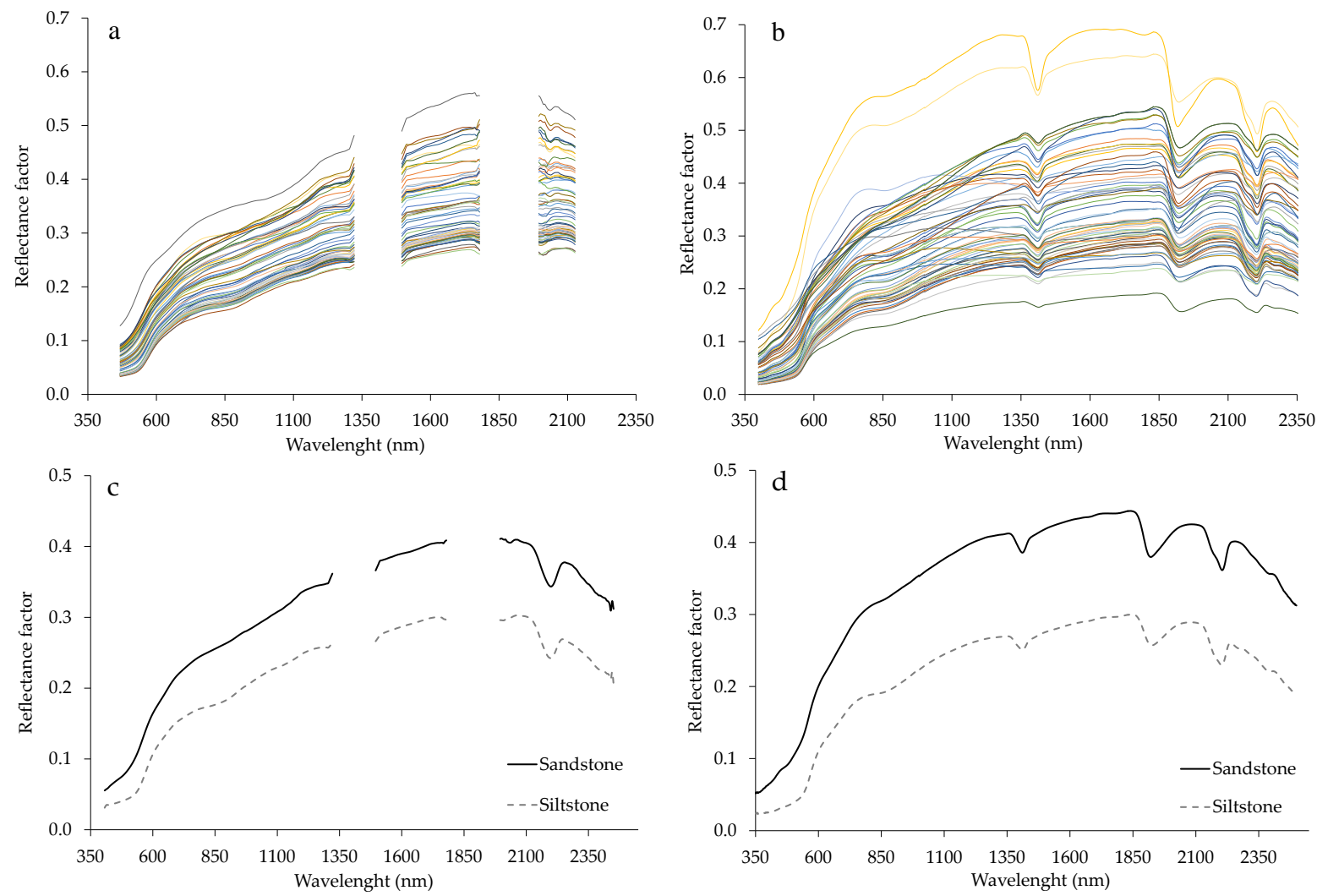

Figure 4. Spectral curves of soil samples. Curves of the 66 samples obtained by the AisaFENIX Sensor (a) and ASD FieldSpec 3 JR Sensor (b); average of spectral data from sandstone and siltstone obtained by the AisaFENIX Sensor (c) and ASD FieldSpec 3 JR Sensor (d). The gap in the curves of the AisaFENIX sensor is due to the absorption of EMR by the atmosphere. 


\subsection{Prediction Models Generated for Particle-Size Fraction and SOM from Spectral Data Obtained} by ASD FieldSpec $3 \mathrm{Jr}$ and AisaFENIX Sensors

Table 4 presents model parameters and performance indicators for soil attributes obtained through data modeling using the PLSR technique for both sensors. During the process for obtaining the PLSR models (Table 4), the relationship between the predictor variables (reflectance) and the predicted (attributes) were better explained for the nonimaging sensor by using the models containing: 10 factors for clay, five factors for silt, four factors for sand and eight factors for SOM. For the imaging sensor, the model presented five factors for clay, four factors for sand and three factors for SOM.

Table 4. Statistical parameters of PLSR models to the FieldSpec $3 \mathrm{Jr}$ and AisaFENIX sensor.

\begin{tabular}{|c|c|c|c|c|c|c|c|c|}
\hline Sensor & Attributes & $\begin{array}{c}\text { PLS } \\
\text { Factors }\end{array}$ & PLSR & $\mathbf{r}$ & $\mathbf{R}^{2}$ & RMSE & SE & Bias \\
\hline \multirow{2}{*}{ Non-imaging } & \multirow{4}{*}{ Clay $\left(\mathrm{g} \mathrm{kg}^{-1}\right)$} & \multirow[t]{2}{*}{10} & $\begin{array}{c}\text { Cross- } \\
\text { Validation }\end{array}$ & 0.902 & 0.817 & $61.131_{\mathrm{cV}}$ & $61.304_{\mathrm{CV}}$ & 0.817 \\
\hline & & & Prediction & 0.921 & 0.720 & $66.332_{p}$ & $67.532_{\mathrm{p}}$ & 1.038 \\
\hline \multirow{2}{*}{ Imaging } & & \multirow{2}{*}{5} & $\begin{array}{c}\text { Cross- } \\
\text { Validation }\end{array}$ & 0.839 & 0.703 & $81.001_{\mathrm{cv}}$ & $82.183_{\mathrm{cv}}$ & 0.564 \\
\hline & & & Prediction & 0.799 & 0.621 & $81.613_{p}$ & $82.195 p$ & 1.562 \\
\hline \multirow[t]{2}{*}{ Non-imaging } & \multirow{4}{*}{ Silt $\left(\mathrm{g} \mathrm{kg}^{-1}\right)$} & \multirow[t]{2}{*}{5} & $\begin{array}{c}\text { Cross- } \\
\text { Validation }\end{array}$ & 0.444 & 0.211 & $15.533_{\mathrm{cv}}$ & $15.722_{\mathrm{cv}}$ & 0.013 \\
\hline & & & Prediction & 0.491 & 0.175 & $27.082_{\mathrm{p}}$ & $27.701_{\mathrm{p}}$ & -0.291 \\
\hline \multirow[t]{2}{*}{ Imaging } & & \multirow[t]{2}{*}{1} & $\begin{array}{c}\text { Cross- } \\
\text { Validation }\end{array}$ & -0.463 & 0.05 & $24.991_{\mathrm{cv}}$ & $25.261_{\mathrm{cv}}$ & 0.040 \\
\hline & & & Prediction & -0.187 & 0.06 & $39.722_{p}$ & $40.303_{p}$ & -0.586 \\
\hline \multirow[t]{2}{*}{ Non-imaging } & \multirow{3}{*}{ Sand $\left(\mathrm{g} \mathrm{kg}^{-1}\right)$} & \multirow[t]{2}{*}{4} & $\begin{array}{c}\text { Cross- } \\
\text { Validation }\end{array}$ & 0.844 & 0.726 & $77.233_{\mathrm{cv}}$ & $78.164 \mathrm{cv}$ & 0.056 \\
\hline & & & Prediction & 0.842 & 0.544 & $76.041_{p}$ & $75.612_{p}$ & 2.004 \\
\hline \multirow[t]{2}{*}{ Imaging } & & \multirow[t]{2}{*}{4} & $\begin{array}{c}\text { Cross- } \\
\text { Validation }\end{array}$ & 0.837 & 0.690 & $71.482_{\mathrm{cv}}$ & $72.484_{\mathrm{cv}}$ & -0.664 \\
\hline & & & Prediction & 0.818 & 0.663 & $81.851_{\mathrm{p}}$ & $83.882_{p}$ & -0.575 \\
\hline \multirow[t]{2}{*}{ Non-imaging } & & \multirow[t]{2}{*}{8} & $\begin{array}{c}\text { Cross- } \\
\text { Validation }\end{array}$ & 0.893 & 0.805 & $1.613_{\mathrm{cv}}$ & $1.627_{\mathrm{cv}}$ & 0.126 \\
\hline & $\operatorname{SOM}\left(\mathrm{g} \mathrm{dm}^{-3}\right)$ & & Prediction & 0.845 & 0.700 & $1.743_{\mathrm{p}}$ & $1.795_{p}$ & 0.068 \\
\hline \multirow[t]{2}{*}{ Imaging } & & \multirow[t]{2}{*}{3} & $\begin{array}{c}\text { Cross- } \\
\text { Validation }\end{array}$ & 0.802 & 0.672 & $1.778_{\mathrm{cv}}$ & $1.796_{\mathrm{cv}}$ & 0.255 \\
\hline & & & Prediction & 0.845 & 0.672 & $2.158 \mathrm{p}$ & $2.209 p$ & -0.221 \\
\hline
\end{tabular}

$\mathrm{cv}=$ cross-validation; $\mathrm{p}=$ prediction.

For silt, it was not possible to establish a satisfactory model due to the low relation between reflectance obtained for this attribute, as demonstrated by Demattê et al. [56], Nanni and Demattê [57] and Nanni et al. [47].

It was observed that, for cross-validation, both in the imaging sensor and non imaging sensor, the values of $\mathrm{R}^{2}$ varied from 0.70 to 0.81 for clay, from 0.69 to 0.72 for sand, and 0.67 to 0.80 for SOM (Table 4), which, according to Minasny and McBratney [58], are values considered satisfactory. Furthermore, these results corroborate the findings obtained by Paz-Kagan et al. [18], who studied the ability of an imager sensor to estimate attributes of an Israeli soil and found $R^{2}$ values for clay, sand, silt above 0.61. Nanni et al. [47], using a non-imaging sensor, found for clay and sand an $R^{2}$ of 0.89 and 0.92 , respectively. But the authors found $\mathrm{R}^{2}$ for SOM equal to 0.44 , a very low value compared to the results obtained in the present study.

For silt, as expected, the cross-validation models presented low values possibly because of this fraction, in weathered soils, has many different minerals, which confused with clay, Fe and Al oxides, and that can make aggregates with organic matters [47,59]. Furthermore, the difficulty to estimate the silt content occurs because the fraction does not have linear relation with the soil reflectance, but a curvilinear one (hyperbolic), as 
described by Cezar et al. [60]. For both sensors, the bias of cross-validation for clay, sand and $\mathrm{SOM}$ was close to zero, indicating that there was a random point distribution on the regression line, showing no tendency of the values obtained [13]. The standard error (SE) close to the RMSE indicates the good fit of the obtained models [61,62].

The error in the prediction value (RMSEp), for both sensors, in most cases, had a small increase in relation to the cross-validation step (RMSEcv) for all studied attributes (Figure 5). This is due to the reduction in precision between processes due to the decrease in the number of samples used in each step. Even so, the obtained results are satisfactory since no significant error variations were observed, indicating the good prediction capacity of the models [63]. However, the bias value was low, showing that there was no bias in the validation of prediction models. Even with the increase, these values can still suggest good performance for the content estimate of clay, sand and SOM [64]. These results demonstrate that Vis-NIR-SWIR spectroscopy is suitable for the multidimensional evaluation of soil attributes, just as reported by Paz-Kagan et al. [18] and Nanni et al. [47].
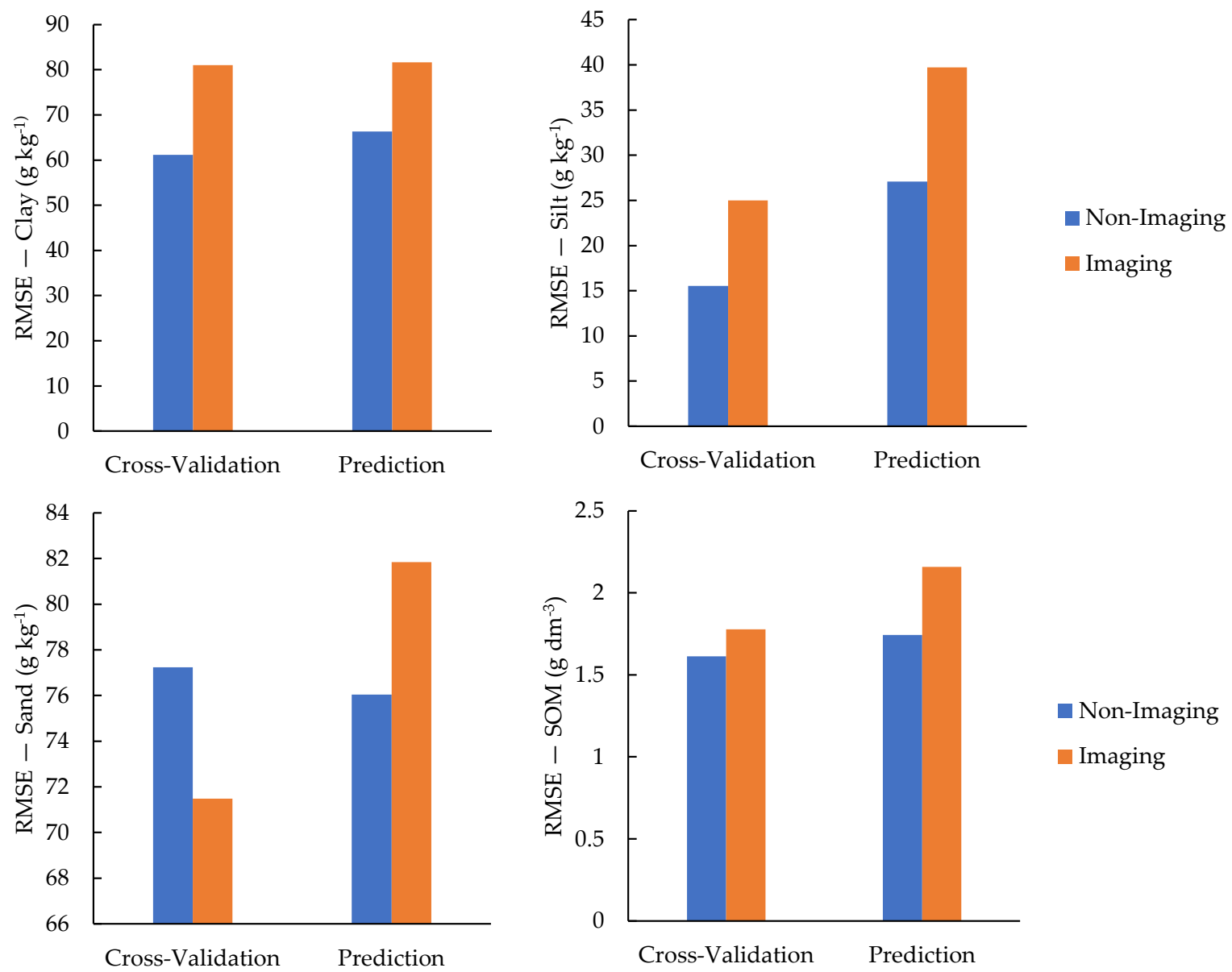

Non-Imaging

Imaging

Figure 5. RMSE values of the PLSR model obtained by the imaging and non-imaging sensors in the cross-validation and prediction phases.

The statistical metrics show that the imaging sensor presented (in the prediction step), except for the silt variable, results similar to that of the non-imaging sensor. This is very promising, since the use of an imaging sensor allows a greater possibility of collecting information from an area, since with this type of sensor it is possible to obtain a spectral curve in each pixel of the image.

Furthermore, the generated models demonstrate the potential to be applied in areas with similar geological and edaphoclimatic characteristics, and further investigations are necessary to evaluate the applicability of this method in areas with different characteristics. 
During the prediction step (non-imaging sensor), values of $\mathrm{r}$ and $\mathrm{R}^{2}$ for clay and SOM remained high (above 0.70 ). For clay, silt, sand and SOM, the results of $\mathrm{R}^{2}$ found in the present work had different results in relation to those practiced by Martins et al. [65], For those same attributes, the results obtained were lower than those found by Paz-Kagan et al. [18], who, studying the use of image spectroscopy to evaluate the soil attributes, found $\mathrm{R}^{2}$ values of $0.87,0.73,0.67$ and 0.95 for clay, silt, sand and SOM determination models, respectively. Although the model has presented very consistent metrics, mainly for the silt attribute, the low number of samples evaluated to create the PLSR model (prediction set $=20$ samples) may have limited the creation of models with higher $\mathrm{R}^{2}$ $p$-values, for example.

According to Hair Jr et al. [66], for multivariate analysis, the recommended sample size is at least 20 samples for each group. The authors stated that larger number of samples generally reduces the sampling error and increases the sensitivity (power) of the test. The set of cross-validation $(n=46)$ and prediction $(n=20)$ of this work are within the aforementioned guideline (although at the limit) and the values of $\mathrm{R}^{2}$ in general were satisfactory. However, it is recommended, for future work, to carry out tests with a larger sample size and to verify the real influence.

For the imaging sensor, in accordance to the error estimates, the models for clay, sand and SOM presented relevant capacity of prediction, with $\mathrm{R}^{2} \mathrm{p}$ of $0.62,0.66$ and 0.67 in the prediction respectively. These results were slightly lower than those obtained by Gomez et al. [67] (clay- $R^{2} p=0.75$ ), Selige et al. [68] (sand- $R^{2} p=0.87$ ) and Schwanghart and Jarmer [69] (SOM-R $\left.{ }^{2} p=0.77\right)$.

The RMSEp, standard error (SEp) and bias parameters, in all evaluated attributes in the prediction, presented low values. The observed low RMSEp values indicate that the model presents high prediction capacity [70]. For bias , the low values indicate that the model is unbiased [71].

The results of the statistical parameters of the models ( $\mathrm{R}^{2}, \mathrm{RMSE}$, bias etc.), are similar between the two sensors. These results demonstrate that the use of the imaging sensor in a tropical environment for clay, sand and SOM determinations, can be as useful as the use of the non-imaging sensor (considered as a standard). In addition, the ability of the imaging sensor to carry out the simultaneous analysis of large areas is an important factor, which can greatly contribute to the generation of soil attribute maps, assisting the decision making of the production process, such as the choice of more suitable crops to the area in question, and even the rational use of correctives and fertilizers. Furthermore, these results are corroborated by other studies using image spectroscopy to determine the particle size and SOM, such as those by Hbirkou et al. [72] and Franceschini et al. [73].

By PLSR definition, all wavelengths participate, in different proportions or weights, in the construction of the model. In this regard, Figure 6 illustrates the regression coefficients for PLSR models of clay, silt, sand and SOM for both sensors, which are considered important to the prediction of these attributes through its determination coefficients $\left(R^{2}\right)$.

For clay and sand, Vis ( 400 to $700 \mathrm{~nm}$ ) and SWIR (2100 to $2400 \mathrm{~nm}$ ) regions presented high values of regression coefficients for the both sensors (Figure 6), indicating that these regions of the electromagnetic spectrum presents characteristics to predict these attributes. These results were expected for clay, since the Vis wavelengths (around to $600 \mathrm{~nm}$ ) are mainly associated to minerals that have iron, e.g., hematite and goethite, which are frequent in Brazilian highly weathered soils [74-76], and the absorption in the SWIR range is due to soil clay minerals [23,77]. More specifically, in the SWIR region, at 2189 and $2260 \mathrm{~nm}$, the highest values of regression coefficients were due to kaolinite and gibbsite, respectively, which are typical minerals of clay fraction in the tropical soils [78,79]. Around 1400 and $1900 \mathrm{~nm}$, the highest values of regression coefficients were possibly obtained as a result from $\mathrm{OH}$ - groups of silicate clays, which are present in the samples [80]. For sand, at 1453 and $1910 \mathrm{~nm}$, may be associated with minerals 2:1 covering over the quartz particles [79]. For silt attribute, the regression coefficients for the non-imaging sensor 
(Figure 6) and imaging sensor do not explain the PLSR model due to low $r$ and $R^{2}$ values (Table 4).
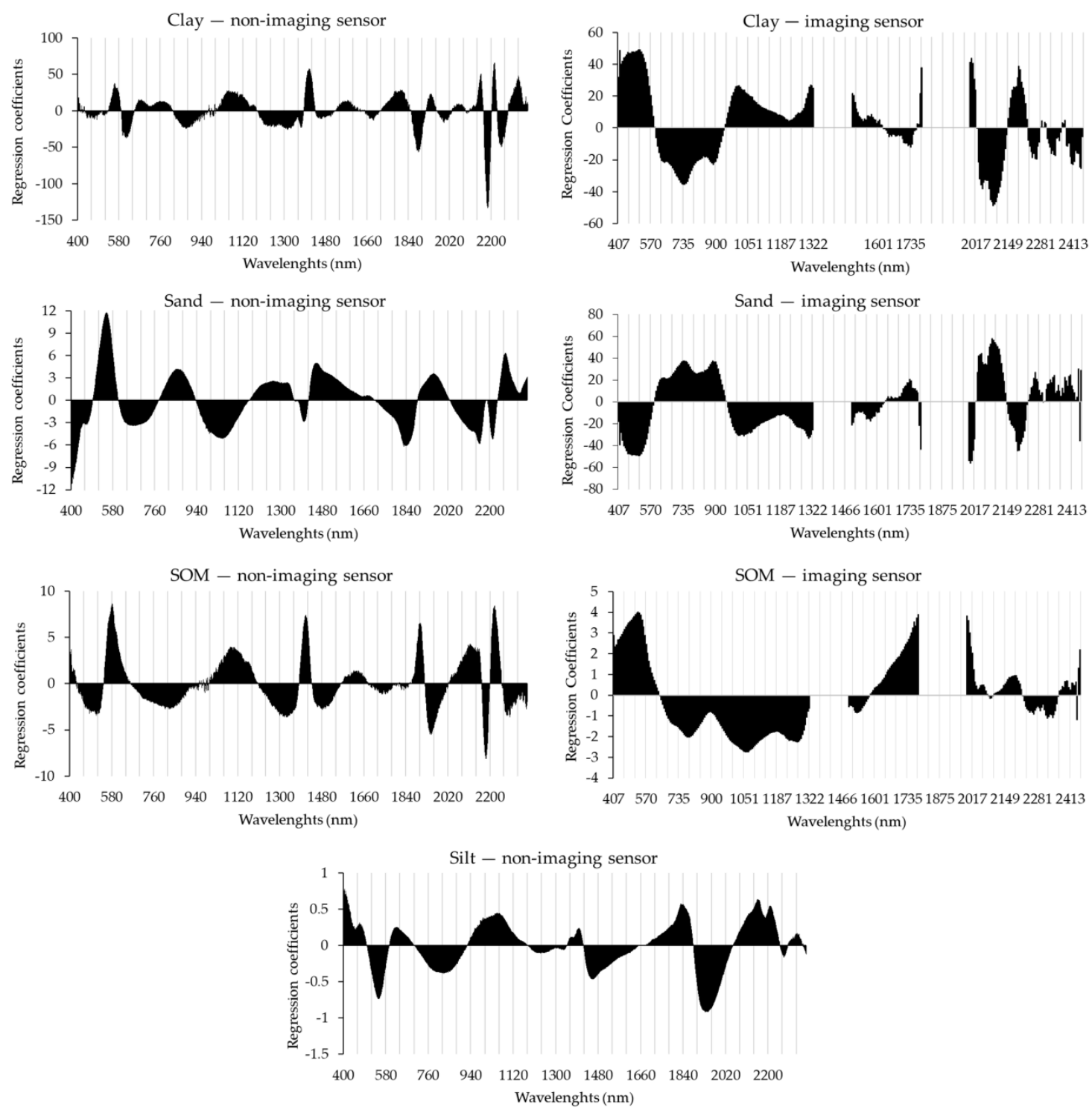

Figure 6. Regression coefficients of PLSR models for imaging and non-imaging sensors for prediction of clay, sand, SOM and silt.

The highest values of regression coefficients for SOM for the imaging sensor (Figure 6) were found in the wavelengths between 400 and $600 \mathrm{~nm}$, and between 1700 and $1900 \mathrm{~nm}$, in agreement with Nawar et al. [81]. For the non-imaging sensor (SOM), observed high values of regression coefficients in wavelengths around 580, 1401, 1900-1940, 2180 and $2220 \mathrm{~nm}$, agreeing with Chen et al. [8], Viscarra Rossel and Hicks [82] and Yang and Li [83]. These results were possibly found because of the interaction between organic matter and iron oxides $(580 \mathrm{~nm})$ and kaolinite $(2220 \mathrm{~nm})$ [84]. On the order hand, for both sensors, the high values of regression coefficients in wavelengths around 1401 and 1900-1940 nm come from water molecules vibrations and $\mathrm{OH}$ - associated with the SOM [52].

Pearson's correlation was performed between the estimated contents of clay, sand, and SOM by the imaging and non-imaging sensors through PLSR models, as shown in Figure 7. Significant positive correlations were observed, with an alpha significance level of $5 \%$ and $p$ value lower than 0.0001 , among the contents estimated of clay (0.858), sand (0.849), and SOM (0.897) by the PLSR models for the imaging and non-imaging sensors. This high 
correlation is due to the similarity between the curves, which provided similarity between the PLSR models of the sensors. These results are corroborated by the study of Franceschini et al. [73], who, evaluating the ability to predict SOM, clay and sand from an imaging and another non-imaging sensor, found similar relationships between these sensors.
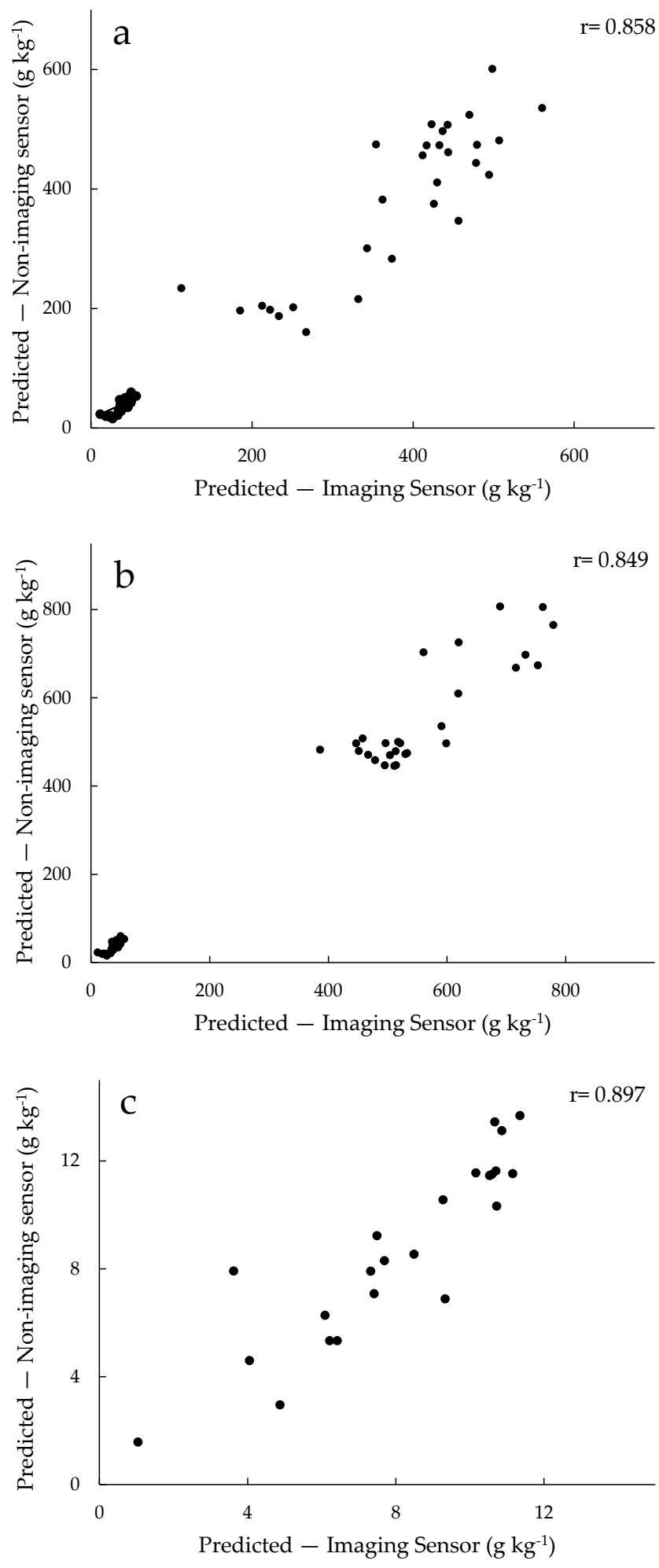

Figure 7. Pearson's correlation (with an alpha significance level of $5 \%$ and $p$ value lower than (0.0001) between the contents predicted of clay (a), sand (b), and SOM (c) by PLSR models for imaging and non-imaging sensors. 


\subsection{Attributes Mapping Using PLSR Models}

Pixel based spatial distribution maps for each soil attribute are shown in Figure 8 using the best cross validated regression models from the airborne imaging sensor.

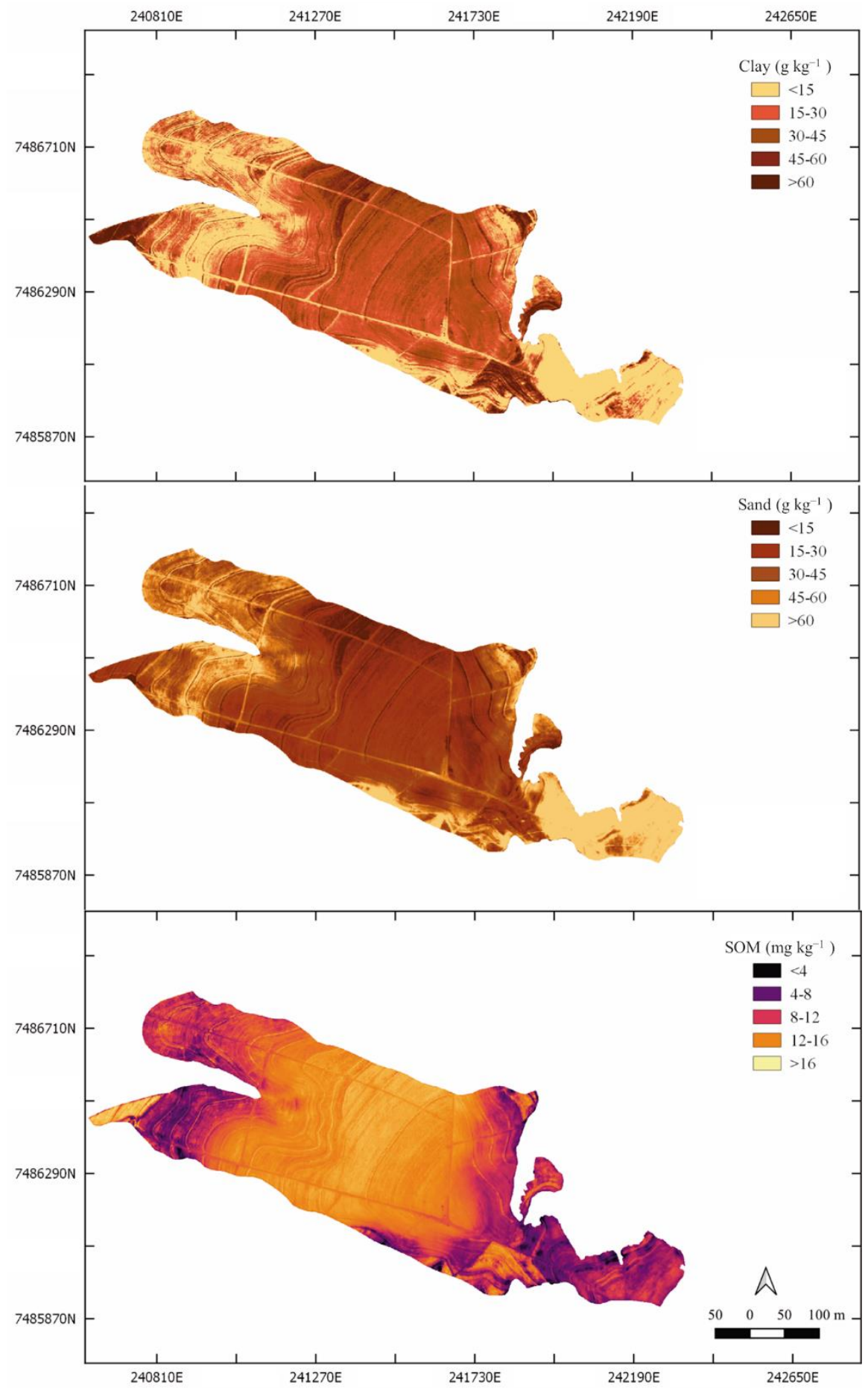

Figure 8. Estimated map of contents of (top) clay, (middle) sand, and (bottom) SOM of study area soils obtained using an airborne imaging sensor.

The mathematical model generated by PLSR in the calibration step for clay, sand and SOM were applied to all pixels from the image. The result was a quantification map for each pixel, divided into classes for better representation and visualization. As the soil attributes presented a strong correlation with the image sensor data (Table 4), it was 
possible to quantify the estimates of interest. Similarly, Pullanagari et al. [85], mapped nutrients in pasture using classification algorithms.

It can be seen in Figure 8 that the highest levels of clay were found in the highest (and flat) portions of the landscape and the areas of the lowest (and steepest) portions have higher levels of sand. These results are in agreement with the results found in the samples analyzed in the laboratory and are also in agreement with Vidal-Torrado and Lepsch [33], working in the same area, who found clay contents in horizon A ranging from 16 to $58 \%$. In addition, it is noted that it was possible to identify, through the map, areas with higher levels of clay on the terrace (marked with waypoints). These results were due to the exposure of the clayey horizon, typical of the Ultisols present in the area.

The highest levels of organic matter were found in portions of the landscape with the highest levels of clay. In fact, it is expected that the levels of organic matter are related to the texture of the soil. Lepsch [86] found a high correlation between the carbon and clay contents of the superficial horizon. Indeed, due to soil management for sugarcane, the soil is plowed and harrowed. With soil mobilization, the decomposition of SOM increases through its greater exposure to microbial attack. In portions with higher clay levels, the process is minimized, due to the higher humidity and lower temperature. On the other hand, as with more sandy portions, the opposite occurs. Lower water absorption increases the temperature of the soil and, therefore, greater decomposition of sound in these areas. In addition, higher levels of SOM can be observed within the terrace, possibly caused by the accumulation of this attribute through an erosive process.

The spatial distribution maps of content of soil attributes are information that becomes important for decision making at the time of planting, since physical attributes and organic matter are essential for a relevant crop. Moreover, this study contributes to understand the optimum analysis methods when mapping soil attributes at a regional, national or global scale using spaceborne imaging spectrometers.

\section{Conclusions}

The prediction of particle size and soil organic matter through hyperspectral imaging and non-imaging sensors yielded comparable results to traditional analytical techniques. It was possible to carry out the quantification of the clay $\left(R^{2}>0.62\right)$, sand $\left(R^{2}>0.54\right)$ and SOM $\left(R^{2}>0.67\right)$ attributes through the use of data obtained by the hyperspectral imaging and non-imaging sensors.

Furthermore, highly significant positive correlations were observed among the estimated contents of clay (0.858), sand (0.849), and SOM (0.897) by the PLSR models for the imaging and non-imaging sensors.

Our study successfully generated large-scale and detailed soil prediction maps by the imaging sensor for particle size and SOM. Considering that Brazil is mainly occupied by large agricultural areas, the possibility of generating large-scale soil attributes prediction maps allows better knowledge about soil attributes (particle size and SOM) important to the management of tropical agricultural production.

Author Contributions: Conceptualization: M.R.N., J.A.M.D. Methodology: M.R.N., J.A.M.D. Software, L.G.T.C., R.H.F., M.R. and E.C. Formal analysis: L.G.T.C., M.R.N., E.C., G.L.A.A.d.S., A.S.R., M.R. and K.M.d.O. Data curation: M.R.N., E.C., J.A.M.D., R.H.F., M.R. Writing-original draft preparation: M.R.N., J.A.M.D., L.S. and L.G.T.C. Visualization: L.G.T.C., M.R.N. and L.S. Project administration: M.R.N., J.A.M.D. and L.S. Funding acquisition: J.A.M.D., M.R.N., and L.S. All authors have read and agreed to the published version of the manuscript.

Funding: This work has been funded by the Coordination of Superior Level Staff ImprovementCAPES, through a postdoctoral fellowship grant to the first author and resources to carry out the project analyses foreseen; National Council for Scientific and Technological Development-CNPq; Brazilian Innovation Agency-FINEP [C. 0673/13]; Central Public-Interest Scientific Institution Basal Research Fund [Y2021GH18] and the Talented Young Scientist Program-China Science and Technology Exchange Center [Brazil-19-004]. 
Institutional Review Board Statement: Not applicable.

Informed Consent Statement: Not applicable.

Data Availability Statement: The data that support the findings of this study are available from the author M.R.N.

Conflicts of Interest: The authors declare no conflict of interest.

\section{References}

1. Cezar, E.; Nanni, M.R.; Demattê, J.A.M.; Chicati, M.L.; de Oliveira, R.B. Estimativa de atributos do solo por meio de espectrorradiometria difusa. Rev. Bras. Ciênc. Solo 2013, 37, 858-868. [CrossRef]

2. Mendonça-Santos, M.L.; dos Santos, H.G. The state of the art of Brazilian soil mapping and prospects for digital soil mapping. Dev. Soil Sci. 2006, 31, 39-54. [CrossRef]

3. Santos, H.G.; Hochmüller, D.P.; Cavalcanti, A.C.; Rêgo, R.S.; Ker, J.C.; Panoso, L.A.; Amaral, J.A.M. Procedimentos Normativos de Levantamentos Pedológicos; Embrapa-SPI: Brasília, Brazil; Embrapa-CNPS: Rio de Janeiro, Brazil, 1995.

4. Busato, J.G.; Leão, T.P.; Baldotto, M.A.; Canellas, L.P. Organic matter quality and dynamics in tropical soils amended with sugar industry residue. Rev. Bras. Ciênc. Solo 2012, 36, 1179-1188. [CrossRef]

5. Weil, R.R.; Brady, N.C. The Nature and Properties of Soils, 15th ed.; Pearson: Columbus, OH, USA, 2016.

6. Demattê, J.A.M.; Ramirez-Lopez, L.; Rizzo, R.; Nanni, M.R.; Fiorio, P.R.; Fongaro, C.T.; Neto, L.G.M.; Safanelli, J.L.; Barros, P.P.D.S. Remote sensing from ground to space platforms associated with terrain attributes as a hybrid strategy on the development of a pedological map. Remote Sens. 2016, 8, 826. [CrossRef]

7. Sousa Junior, J.G.; Demattê, J.A.M.; Araújo, S.R. Modelos espectrais terrestres e orbitais na determinação de teores de atributos dos solos: Potencial e custos. Bragantia 2011, 70, 610-621. [CrossRef]

8. Chen, S.; Li, S.; Ma, W.; Ji, W.; Xu, D.; Shi, Z.; Zhang, G. Rapid determination of soil classes in soil profiles using vis-NIR spectroscopy and multiple objectives mixed support vector classification. Eur. J. Soil Sci. 2019, 70, 42-53. [CrossRef]

9. Ji, W.; Li, S.; Chen, S.; Shi, Z.; Viscarra Rossel, R.A.; Mouazen, A.M. Prediction of soil attributes using the Chinese soil spectral library and standardized spectra recorded at field conditions. Soil Tillage Res. 2016, 155, 492-500. [CrossRef]

10. Lee, K.S.; Sudduth, K.A.; Drummond, T.S.; Lee, D.H.; Kitchen, N.R.; Chung, S.O. Calibration methods for soil property estimation using reflectance spectroscopy. ASABE 2010, 53, 675-684. [CrossRef]

11. Viscarra Rossel, R.A.; Cattle, S.R.; Ortega, A.; Fouad, Y. In situ measurements of soil colour, mineral composition and clay content by vis-NIR spectroscopy. Geoderma 2009, 150, 253-266. [CrossRef]

12. Demattê, J.A.M.; Alves, M.R.; Gallo, B.C.; Fongaro, C.T. Detecção de limites de solos por dados espectrais e de relevo. Rev. Bras. Ciênc. Solo 2014, 38, 718-729. [CrossRef]

13. Cezar, E.; Nanni, M.R.; Guerrero, C.; da Silva Junior, C.A.; Cruciol, L.G.T.; Chicati, M.L.; Silva, G.F.C. Organic matter and sand estimates by spectroradiometry: Strategies for the development of models with applicability at a local scale. Geoderma 2019, 340, 224-233. [CrossRef]

14. Liu, H.J.; Zhang, X.L.; Zheng, S.F.; Tang, N. Black soil organic matter predicting model based on field hyperspectral reflectance. Spectr. Spec. Anal. 2010, 30, 3355-3358. [CrossRef]

15. Shi, Z.; Ji, W.; Viscarra Rossel, R.A.; Chen, S.; Zhou, Y. Prediction of soil organic matter using a spatially constrained local partial least squares regression and the Chinese vis-NIR spectral library. Eur. J. Soil Sci. 2015, 66, 679-687. [CrossRef]

16. Demattê, J.A.M.; Garcia, G.J. Alteration of Soil Properties through a Weathering Sequence as Evaluated by Spectral Reflectance. Soil Sci. Soc. Amer. J. 1999, 63, 327. [CrossRef]

17. Vasques, G.M.; Demattê, J.A.M.; Rossel, R.; Ramírez-López, L.; Terra, F.S. Soil classification using visible/near-infrared diffuse reflectance spectra from multiple depths. Geoderma. 2014, 223, 73-78. [CrossRef]

18. Paz-Kagan, T.; Zaady, E.; Salbach, C.; Schmidt, A.; Lausch, A.; Zacharias, S.; Notesco, G.; Ben-Dor, E.; Karnieli, A. Mapping the spectral soil quality index (SSQI) using airborne imaging spectroscopy. Remote Sens. 2015, 7, 15748-15781. [CrossRef]

19. Li, S.; Shi, Z.; Chen, S.; Ji, W.; Zhou, L.; Yu, W.; Webster, R. In situ measurements of organic carbon in soil profiles using vis-NIR spectroscopy on the Qinghai-Tibet plateau. Environ. Sci. Technol. 2015, 49, 4980-4987. [CrossRef]

20. Viscarra Rossel, R.A.; Lobsey, C.R.; Sharman, C.; Flick, P.; McLachlan, G. Novel proximal sensing for monitoring soil organic C stocks and condition. Environ. Sci. Technol. 2017, 51, 5630-5641. [CrossRef]

21. Richter, K.; Palladino, M.; Vuolo, F.; Dini, L.; D’Urso, G. Spatial distribution of soil water content from airborne thermal and optical remote sensing data. Remote Sens. Agric. Ecosyst. Hydrol. XI 2009, 7472, 74720W-11. [CrossRef]

22. Sobrino, J.A.; Franch, B.; Mattar, C.; Jiménez-Muñoz, J.C.; Corbari, C. A method to estimate soil moisture from Airborne Hyperspectral Scanner (AHS) and ASTER data: Application to SEN2FLEX and SEN3EXP campaigns. Remote Sens. Environ. 2012, 117, 415-428. [CrossRef]

23. Ben-Dor, E.; Taylor, R.G.; Hill, J.; Dematte, J.A.M.; Whiting, M.L.; Chabrillat, S.; Sommer, S. Imaging spectrometry for soil applications. Adv. Agron. 2008, 97, 321-392. [CrossRef] 
24. Goetz, A.F.H.; Vane, G.; Solomon, J.E.; Rock, B.N. Imaging spectroscopy for earth remote sensing. Science 1985, 228, 1147-1153. [CrossRef] [PubMed]

25. Green, R.O.; Eastwood, M.L.; Sarture, C.M.; Chrien, T.G.; Aronsson, M.; Chippendale, B.J.; Faust, J.A.; Pavri, B.E.; Chovit, C.J.; Solis, M. Imaging spectroscopy and the airborne visible/infrared imaging spectrometer (AVIRIS). Remote Sens. Environ. 1998, 65, 227-248. [CrossRef]

26. Rodrigues, M.; Nanni, M.R.; Cezar, E.C.; Santos, G.L.A.A.; Reis, A.S.; Oliveira, K.M. Evaluation of the use of spectroradiometry for the determination of soil exchangeable ions after the application of mining coproducts. Appl. Spec. Rev. 2020, 25, 491-508. [CrossRef]

27. Bonfatti, B.R.; Demattê, J.A.; Marques, K.P.; Poppiel, R.R.; Rizzo, R.; Mendes, W.S.; Nelida EQ Silvero, N.E.Q.; Safanelli, J.L. Digital mapping of soil parent material in a heterogeneous tropical area. Geomorphology 2020, 367. [CrossRef]

28. IPT-Instituto de Pesquisas Tecnológicas. Mapa Geológico do Estado de São Paulo. Escala 1:1.000.000; Divisão de Minas e Geologia Aplicada do Instituto de Pesquisas Tecnológicas do estado de São Paulo: São Paulo, Brazil, 1981.

29. Marques, K.P.; Demattê, J.A.; Miller, B.A.; Lepsch, I.F. Geomorphometric segmentation of complex slope elements for detailed digital soil mapping in southeast Brazil. Geoderma Reg. 2018, 14. [CrossRef]

30. Rossi, M. Pedological Map of the State of São Paulo: Revised and Expanded, 1st ed.; Instituto Florestal: São Paulo, Brazil, 2017.

31. Souza Filho, E.E. Mapeamento Faciológico do Subgrupo Itararé na Quadrícula de Campinas (SP). Master's Thesis, Universidade de São Paulo, São Paulo, Brazil, 1986.

32. Vidal-Torrado, P. Pedogênese e Morfogênese no Distrito de Tupi (Piracicaba, SP). Ph.D. Thesis, Escola Superior de Agricultura Luiz de Queiroz, Universidade de São Paulo, São Paulo, Brasil, 1994. [CrossRef]

33. Vidal-Torrado, P.; Lepsch, I.F. Relações material de origem/solo e pedogênese em uma seqüência de solos predominantemente argilosos e latossólicos sobre psamitos na Depressão Periférica Paulista. Rev. Bras. Ciên. Solo 1999, 23, 357-369. [CrossRef]

34. Teixeira, P.C.; Donagemma, G.K.; Fontana, A.; Teixeira, W.G. Manual de Métodos de Análise de Solos, 3rd ed.; Revisada e Ampliada; Embrapa: Brasília, Brazil, 2017.

35. Epiphânio, J.C.N.; Formaggio, A.R.; Valeriano, M.D.M.; Oliveira, J.D. Comportamento Espectral de Solos do Estado de São Paulo, 1st ed.; INPE: São José dos Campos, Brazil, 1992.

36. LRCL-Labsphere Reflectance Calibration Laboratory. Spectral Reflectance Target Calibrated From 0.25-2.5 $\mathrm{nm}$ Reported in 0.050 $\mathrm{nm}$ Intervals, 1st ed.; Sutton: London, UK, 2009.

37. Nanni, M.R.; Demattê, J.A.M. Comportamento da linha do solo obtida por espectrorradiometria laboratorial para diferentes classes de solo. Rev. Bras. Ciênc. Solo 2006, 30, 1031-1038. [CrossRef]

38. Ben-Dor, E.; Ong, C.; Lau, I.C. Reflectance measurements of soils in the laboratory: Standards and protocols. Geoderma 2015, 245-246, 112-124. [CrossRef]

39. Fongaro, C.T.; Demattê, J.A.M.; Rizzo, R.; Lucas Safanelli, J.; Mendes, W.D.S.; Dotto, A.C.; Vicente, L.E.; Franceschini, M.H.D.; Ustin, S.L. Improvement of Clay and Sand Quantification Based on a Novel Approach with a Focus on Multispectral Satellite Images. Remote Sens. 1555, 10, 1555. [CrossRef]

40. Spectral Imaging. AisaFENIX Hyperspectral Sensor. User's Manual. 2017. Available online: https://specim.fi/products/ aisafenix/ (accessed on 3 June 2020).

41. Richter, R. Atmospheric/Topographic Correction for Airborne Imagery; DLR Report, DLR-IB 562-02/05; DLR: Wesseling, Germany, 2005; p. 107.

42. Environment For Visualizing Images (Envi Classic) User's Guide; ITT Visual Information Solutions: Boulder, CO, USA, 2005.

43. Summers, D.; Lewis, M.; Ostendorf, B.; Chittleborough, D. Visible near-infrared reflectance spectroscopy as a predictive indicator of soil properties. Ecol. Indic. 2011, 11, 123-131. [CrossRef]

44. Savitzky, A.; Golay, M.J.E. Smoothing and differentiation of data by simplified least squares procedures. Anal. Chem. 1964, 36, 1627-1639. [CrossRef]

45. Buddenbaum, H.; Steffens, M. The effects of spectral pretreatments on chemometric analyses of soil profiles using laboratory imaging spectroscopy. Appl. Environ. Soil Sci. 2012, 1-12. [CrossRef]

46. Rinnan, A.; Berg, F.V.; Engelsen, S.B. Review of the most common preprocessing techniques for nearinfrared spectral. Trac Trends Anal. Chem. 2009, 28, 1201-1222. [CrossRef]

47. Nanni, M.R.; Cezar, E.; Silva Junior, C.A.D.; Silva, G.F.C.; Gualberto, A.A.S. Partial least squares regression (PLSR) associated with spectral response to predict soil attributes in transitional lithologies. Arch. Agron. Soil Sci. 2017, 64, 682-695. [CrossRef]

48. Barmeier, G.; Hofer, K.; Schmidhalter, U. Mid-season prediction of grain yield and protein content of spring barley cultivars using high-throughput spectral sensing. Eur. J. Agron. 2017, 90, 108-116. [CrossRef]

49. Almeida, M.R.N. Espectroscopia de Infravermelho Próximo com Transformada de Fourier (FT-NIR) na Caracterização de Farinhas para Alimentação Pueril. Master's Thesis, University of Lisbon, Lisbon, Portugal, 2009.

50. Souza, D.M.; Madari, B.E.; Guimarães, F.F. Application of multivariate calibration and artificial intelligence in the analysis of infrared spectra to quantify organic matter in soil samples. Quim. Nova. 2012, 35, 1738-1745. [CrossRef]

51. Harr, M.E. Reliability-Based Design in Civil Engineering; McGraw-Hill: New York, NY, USA, 1987.

52. Demattê, J.A.M.; Araújo, S.R.; Fiorio, P.R.; Fongaro, C.T.; Nanni, M.R. Espectroscopia VIS-NIR-SWIR na avaliação de solos ao longo de uma topossequência em Piracicaba (SP). Rev. Ciênc. Agron. 2015, 46, 679-688. [CrossRef] 
53. Palm, C.; Sanches, P.; Ahamed, S.; Awiti, A. Soils: A Contemporary Perspective. Annu. Rev. Environ. Resour. 2007, 32, 99-129. [CrossRef]

54. Dalmolin, R.S.D.; Gonçalves, C.N.; Klant, E.; Dick, D.P. Relação entre os constituintes do solo e seu comportamento espectral. Ciênc. Rur. 2005, 35, 481-489. [CrossRef]

55. Demattê, J.A.M.; Bellinaso, H.; Romero, D.J.; Fongaro, C.T. Morphological Interpretation of Reflectance Spectrum (MIRS) using libraries looking towards soil classification. Sci. Agric. 2014, 71, 509-520. [CrossRef]

56. Demattê, J.A.M.; Fiorio, P.R.; Araújo, S.R. Variation of routine soil analysis when compared with hyperspectral narrow band sensing method. Remote Sens. 2010, 2, 1997-2016. [CrossRef]

57. Nanni, M.R.; Demattê, J.A.M. Spectral reflectance methodology in comparison to traditional soil analysis. Soil Sci. Soc. Am. J. 2006, 70, 393-407. [CrossRef]

58. Minasny, B.; McBratney, A. Why you don't need to use RPD. Pedometron 2013, 33, 14-15.

59. Vitorino, A.C.T.; Ferreira, M.M.; Curi, N.; Lima, J.M.; Silva, M.L.N.; Motta, P.E.F. Mineralogia, química e estabilidade de agregados do tamanho de silte de solos da Região Sudeste do Brasil. Pesq. Agropecu. Bras. 2003, 38, 133-141. [CrossRef]

60. Cezar, E.; Nanni, M.R.; Chicati, M.L.; Souza Junior, I.G.; Costa, A.C.S. Avaliação e quantificação das frações silte, argila e areia por meio de suas respectivas reflectâncias. Rev. Bras. Ciênc. Solo 2012, 36, 1157-1165. [CrossRef]

61. Willmott, C.J. Some comments on the evaluation of model performance. Bull. Amer. Meteor. Soc. 1982, 63, 1309-1313. [CrossRef]

62. Mark, H.; Workman, J. Bias and Slope Correction. Spectroscopy 2017, 32, 24-30.

63. Gomes, L.C.; Faria, R.M.; de Souza, E.; Veloso, G.V.; Schaefer, C.E.G.; Fernandes Filho, E.I. Modelling and mapping soil organic carbon stocks in Brazil. Geoderma 2019, 340, 337-350. [CrossRef]

64. Sayes, W.; Mouazen, A.M.; Ramon, H. Potential for onsite and online analysis of pig manure using visible and near infrared reflectance spectroscopy. Bios. Eng. 2005, 91, 393-402. [CrossRef]

65. Martins, J.A.; Fiorio, P.R.; Demattê, J.A.; de Miranda, J.H.; Lelis Neto, J.A. Sensoriamento remoto na determinação de atributos de um Nitossolo sob aplicação de vinhaça. Rev. Bras. Ciênc. Solo 2014, 38, 959-971. [CrossRef]

66. Hair Jr, J.F.; Black, W.C.; Babin, B.J.; Anderson, R.E.; Tatham, R.L. Análise Multivariada de Dados [Recurso Eletrônico], 6th ed.; tradução Adonai Schlup Sant'Anna, Dados eletrônicos; Bookman: Porto Alegre, Brazil, 2009.

67. Gomez, C.; Oltra-Carrió, R.; Bacha, S.; Lagacherie, P.; Briottet, X. Evaluating the sensitivity of clay content prediction to atmospheric effects and degradation of image spatial resolution using Hyperspectral VNIR/SWIR imagery. Remote Sens. Environ. 2015, 164, 1-15. [CrossRef]

68. Selige, T.; Böhner, J.; Schmidhalter, U. High resolution topsoil mapping using hyperspectral image and field data in multivariate regression modeling procedures. Geoderma 2006, 136, 235-244. [CrossRef]

69. Schwanghart, W.; Jarmer, T. Linking spatial patterns of soil organic carbon to topography: A case study from south-eastern Spain. Geomorphology 2011, 126, 252-263. [CrossRef]

70. Boschi, R.S.; Bocca, F.F.; Lopes-Assad, M.L.R.C.; Assad, E.D. How accurate are pedotransfer functions for bulk density for Brazilian soils. Sci. Agric. 2018, 75, 70-78. [CrossRef]

71. El Bouhaddani, S.; Uh, H.W.; Hayward, C.; Jongbloed, G.; Houwing-Duistermaat, J. Probabilistic partial least squares model: Identifiability, estimation and application. J. Multiv. Anal. 2018, 167, 331-346. [CrossRef]

72. Hbirkou, C.; Pätzold, S.; Mahlein, A.K.; Welp, G. Airborne hyperspectral imaging of spatial soil organic carbon heterogeneity at the field-scale. Geoderma 2012, 175-176, 21-28. [CrossRef]

73. Franceschini, M.H.D.; Demattê, J.A.M.; da Silva Terra, F.; Vicente, L.E.; Bartholomeus, H.; de Souza Filho, C.R. Prediction of soil properties using imaging spectroscopy: Considering fractional vegetation cover to improve accuracy. Int. J. Appl. Earth Obs. Geoinf. 2015, 38, 358-370. [CrossRef]

74. Fontes, M.P.F.; Carvalho, A. Color attributes and mineralogical characteristics, evaluated by radiometry, of highly weathered tropical soils. Soil Sci. Soc. Am. J. 2005, 69, 1162-1172. [CrossRef]

75. Mortimore, J.L.; Marshall, L.J.R.; Almond, M.J.; Hollins, P.; Matthews, W. Analysis of red and yellow ochre samples from Clearwell Caves and Çatalhöyük by vibrational spectroscopy and other techniques. Spectr. Acta Part A 2004, 60, 1179-1188. [CrossRef] [PubMed]

76. Sherman, D.M.; Waite, T.D. Electronic spectra of Fe3+ oxides and oxide hydroxides in the near IR to near UV. Am. Min. 1985, 70, 1262-1269.

77. Gomez, C.; Lagacherie, P. Mapping of Primary Soil Properties Using Optical Visible and Near Infrared (Vis-NIR) Remote Sensing. In Land Surface Remote Sensing in Agriculture and Forest; Baghdadi, N., Zribi, M., Eds.; Elsevier: Amsterdam, The Netherlands, 2016; pp. 1-35. [CrossRef]

78. Madeira Netto, J.S. Spectral reflectance properties of soil. Photo Interp. 1996, 34, 59-70.

79. Vicente, L.E.; Souza Filho, C.R. Identification of mineral components in tropical soils using reflectance spectroscopy and advanced spaceborne thermal emission and reflection radiometer (ASTER) data. Remote Sens. Environ. 2011, 115, 1824-1836. [CrossRef]

80. Demattê, J.A.M.; Terra, F.D.S.; Quartaroli, C.F. Spectral behavior of some modal soil profiles from São Paulo State, Brazil. Bragantia 2012, 71, 413-423. [CrossRef]

81. Nawar, S.; Buddenbaum, H.; Hill, J.; Kozak, J.; Mouazen, A.M. Estimating the soil clay content and organic matter by means of different calibration methods of vis-NIR diffuse reflectance spectroscopy. Soil Tillage Res. 2016, 155, 510-522. [CrossRef] 
82. Viscarra Rossel, R.A.; Hicks, W.S. Soil organic carbon and its fractions estimated by visible-near infrared transfer functions. Eur. J. Soil Sci. 2015, 66, 438-450. [CrossRef]

83. Yang, H.; Li, J. Predictions of soil organic carbon using laboratory-based hyperspectral data in the northern Tianshan mountains, China. Environ. Monit. Assess. 2013, 185, 3897-3908. [CrossRef] [PubMed]

84. Fink, J.R.; Inda, A.V.; Tiecher, T.; Barrón, V. Iron oxides and organic matter on soil phosphorus availability. Ciênc. E Agrotec. 2016, 40, 369-379. [CrossRef]

85. Pullanagari, R.R.; Kereszturi, G.; Yule, I.J. Mapping of macro and micro nutrients of mixed pastures using airborne AisaFENIX hyperspectral imagery. ISPRS J. Photog. Remote Sens. 2016, 117, 1-10. [CrossRef]

86. Lepsch, I.F. Influência do cultivo de Eucalyptus e Pinus em propriedades de solo sob cerrado. Rev. Bras. Ciênc. Solo 1980, 4 , 103-107. 